\title{
Raising Students' Vocabulary Mastery Using Selected Game: Using Chalk Down, Turn-around for EYL Students
}

\author{
Sri Ningsih ${ }^{1}$, Indra Bulan ${ }^{2}$, Antonius Ali Wutun ${ }^{3}$ \& Fitri Arniati ${ }^{4}$ \\ ${ }^{1}$ Akademi Kebidanan Tahirah Al Baeti Bulukumba. Indonesia \\ 2, 3,4 STKIP-YPUP Makassar, Makassar. Indonesia \\ fitriarniati168@gmail.com
}

\section{ARTICLE HISTORY}

Received : 2019-06-28

Revised : 2019-07-03

Accepted : 2019-10-08

\section{KEYWORDS}

Chalk Down

Turn Around Game

Students'vocabulary

\begin{abstract}
Based on the 2013 curriculum, students are expected to master common vocabulary in academic text. However, in reality, the above goal has not been achieved. It can be proven by the fact that students still have a common vocabulary and using incorrect words. During the pre-observation, students often experience learning obstacles while learning English. The purpose of this study was to determine the use of Chalk Down, Turn Around Game for improving students' vocabulary mastery at grade VIII SMP Negeri 1 Bambang. This study used a pre-experimental method in the form of one class given a pretest and post-test. The number of students involved 20 students and selected using the total sampling technique. The results of the data showed that the mean score on the post-test is higher than the pre-test $(85>60.25)$, and the t-test value is higher than the t-table score $(11,049>2,092)$ at the level of increase of 0.05 with degree freedom (df) 19. It means that the use of the Chalk Down, Turn Around Game can improve students' vocabulary.
\end{abstract}

\section{Introduction}

Learning English is one aspect that can support someone's ability to develop their potential in mastering the international language. To achieve optimal English language proficiency, it is also necessary to know three language elements that play an essential role in supporting English four skills, i.e., grammar, pronunciation, and vocabulary. It is one of the most important aspects of learning and understanding a language, vocabulary is characterized generally as the awareness of words and their meaning (Yuliana 2011; Sari, Asahra and Yana, 2019). To teach vocabulary to students based on the 2013 curriculum, They are required to learn common vocabulary in academic texts, as well as vocabulary to understand academic, social reading, and listening texts, before moving on to the other basic skills in higher education (Wantini, 2010; Yuliani, 2017; Hakim and Syafei, 2018).

Vocabulary becomes accustomed to different spelling patterns for part of speech, to learn strategies for understanding vocabulary in the text, to use the correct forms of the word in the production of spoken and written language, to develop an understanding of the collection, to understand separate meanings of words as they are used in reading and listening texts. However, the aforementioned goal has not been met. It is shown by the fact that students prefer to use incorrect words and have a common vocabulary. For example, a student writes the sentence as follows, "I met with Dr. yusran on the street" the word "yusran" is incorrect because the first letter of the person's name must use uppercase letters (Lestiyaningsih, 2017, p.24).

When considering English word lists, one factor to remember is the teacher's condition and whether it is a more general academic (i.e., EAP or ESP) English learning and teaching background (Lessard-Clouston, 2013). (During the pre-observation, one respondent (teacher) at SMP Negeri 1 Bambang said that students often experience learning obstacles while learning English. The obstacles are difficulty in listening to English pronunciation, understanding the reading text, arranging words incorrect sentences, and speaking English. The root of these problems is a student's lack of vocabulary (Maritha and Dakhi, 2018; Israilovich, 2019). It would be difficult for the learner who just knows grammar and has no language to articulate what he or she needs to say (Rosyidah, 2018). So, the researcher concludes that internal and external factors can influence the lack of student vocabulary.

Internal factors that can affect their vocabulary are motivation, self-confidence, interest in learning English, etc. An external factor that can affect students' vocabulary is strategy, technique, and also the media. However, seeing from SMP Negeri 1 Bambang's learning condition, Students still need learning methods to motivate their interest in learning English. Teachers are responsible for finding out interesting and attractive ways to teach and motivate 
their students (Sahar, 2016). Learning must be driven by the environment and the learning content. The use of media in vocabulary teaching is important and recommended in this case as it helps students develop their vocabulary. Many different types of media, such as images, videos, and games, may be used to teach vocabulary.

There are previous studies related to this topic. The first research was conducted by Anisa (2011) entitled "Improving Students' Vocabulary Mastery Using Experiential Learning", with a classroom action research, this study found that using this strategy have increased students' vocabulary mastery in terms of improving of understanding meaning, spelling and the using of words. The second research was conducted by Handayani (2012) with the title "Improving the Students' Vocabulary Mastery Using Montessori Method" which is found that the method has enhanced the students' vocabulary mastery in all aspects; meaning, pronunciation, spelling and the words use. The next research was conducted by Cahyani (2018) which entitled 'Improving Students' Vocabulary Mastery by Using Charades", this study revealed that the implementation of Charades can improve students' vocabulary during the cycles conducted. Almost all students could achieve the Minimum Passing Criterion that was 75.

There are many English teaching vocabulary games like ball throwing games, secret word games, turn-around games, etc. In this case, the researcher used the chalk down and turned around the game because it has several advantages. One is to attract students' interest in learning English to not feel bored following the ongoing vocabulary game (Gallant, 2016). Students can spell, understand, and remember every word they write on the board when playing this game.

Based on the explanation above, the researcher will highlight the significant questions "Is chalk down, turn around game to improve students' vocabulary at the Second Grade of SMP Negeri 1 Bambang?". This research aims to determine whether the use of chalk down, turn around game can improve students' vocabulary at the Second Grade of SMP Negeri 1 Bambang. Through this research, students will understand vocabulary by practicing the game, so they will not get bored quickly learning English. It would also be easier for the teacher to teach English to students by playing and teaching vocabulary so that there are no repetitive terms in learning. Furthermore, this research is expected to increase the standard of education and school performance.

\section{Method}

\subsection{Research Types and Data Collection}

This pre-experimental method with one group pre-test, treatment, and post-test, represented with design statistics as follows:

\section{$\mathrm{O}_{1} \times \mathrm{O}_{2}$}

Where :

$01=$ Pre-test

$02=$ Treatment

03 = Post-test.

This research population is the second grade of SMP Negeri 1 Bambang, with the total number of students is 20 that consists of one class only. Therefore, this research will use the total sampling technique, where the researcher will use the whole 20 students in Second Grade that consist of one class only.

This researcher will use the text as an instrument. The instrument will use pre-test, treatment, and posttest (20 items).

\subsection{Technique of Data Analysis}

The data attained from the test analysed by using the following procedure:

The result of pre-test and post-test of the students answer:

1) Scoring The students correct answer $=1$

2) The students wrong answer $=0$

$$
\text { Score }=\frac{\text { TotalCorrectAnswer }}{\text { Numberofitems }} \times 100
$$

(Gay, 2012)

a) Classifying the students score into the following criteria:

1) Score 96-100 classified as excellent

2) Score $86-95$ classified as very good

3) Score 76-85 classified as good

4) Score 66-75 classified fairly good

5) Score 56-65 classified as fair

6) Score 36-55 classified as poor

7) Score 0-35 classified as very poor

b) Computing the frequency of the rate percentage of the students' score

$$
\mathrm{P}=\frac{F}{N} \times 100 \%
$$

Where:

$$
\begin{array}{ll}
\mathrm{P} & \text { : Percentage } \\
\mathrm{F} & \text { : Frequency } \\
\mathrm{N} & \text { : Total number of students }
\end{array}
$$

c) Calculating the mean score of the students by using the following formula

$$
\mathrm{X}=\frac{\sum \mathrm{x}}{N}
$$

Where:

X : Mean Score 
$\sum X \quad$ : The sum of all score

$\mathrm{N} \quad$ : The total number of subject

Gay, 2012)

d) Finding the mean score of the difference score by using the formula

$$
D=\frac{\sum D}{N}
$$

Where :

$\mathrm{D}$ : The mean score

$\sum \mathrm{D}:$ The sum of the difference score

$\mathrm{N}$ : The total number of sample

(Gay, 2012)

e) Calculating the result of the test

To assess the varying significance between the pre-test score and the post-test researcher, the test value is determined using the following formula

$$
\mathrm{t}=\frac{D}{\sqrt{\Sigma D 2-\frac{\frac{(\Sigma D)^{2}}{N}}{N(N-1)}}}
$$

$$
\begin{aligned}
& \text { Where: } \\
& \mathrm{T}: \text { the test of significance } \\
& \mathrm{D}: \text { score change } \\
& \Sigma \mathrm{D}: \text { the man of different score }
\end{aligned}
$$

$$
\mathrm{N} \text { : total number of sample }
$$

(Gay, 2012)

\section{Findings}

Based on the previous chapter's problem statement, the research aimed to know whether chalk down, Turn Around Game could improve the students' vocabulary at the second grade of SMP Negeri 1 Bambang. This research was obtained from the students' scores of pre-test and post-test, the frequency and rate percentage of the students' scores, and the mean score.

\subsection{The Students' Pre-test and post-test}

The pre-experimental method was a class that Chalk Down taught, Turn Around Game. This class was given a pre-test before treatment. The pre-test was given to know the students' achievement in vocabulary, while the post-test was given to know the student achievement after getting the treatment by using Chalk Down, Turn Around Game. During the treatment, the researcher gave some vocabulary for the students to be used in Chalk Down, Turn Around Game. The instrument used in this research was a vocabulary test with two kinds of tests, multiple choices and matching words.

The classifying the score of the student's pre-test and post-test into seven levels as follows:

Table 1. Levels of Pre-test and Post-test Scores

\begin{tabular}{ccc}
\hline No. & Classification & Range of Score \\
\hline 1. & Excellent & $96-100$ \\
2. & Very Good & $86-95$ \\
3. & Good & $76-85$ \\
4. & Fairly Good & $66-75$ \\
5. & Fair & $56-65$ \\
6. & Poor & $36-55$ \\
7. & Very Poor & $0-35$ \\
\hline
\end{tabular}

\subsubsection{The Result of Pre-test}

As has been explained in the collection data. The writer used a vocabulary test for pre-test and post-test. The classification of the pre-test was applied before treatments, whereas the post-test was given after giving treatment. The test was the same.
The students' pre-test from the second grade of students' of SMP Negeri 1 Bambang shows that the lowers score of pre-test was 35 and the highest was 75 from the total number of students was 20 . It can be concluded that the students were lack of vocabulary.

Where:

$$
\begin{array}{ll}
\mathrm{N} & =\text { The total number of Sample } \\
\sum x^{1} & =\text { The total score of student's pre-test }
\end{array}
$$


Table 2. Classification, Frequency, and Percentage of the Students' Pre-test.

\begin{tabular}{lcccc} 
& Classification & Score & \multicolumn{2}{c}{ Pre-Test } \\
\cline { 3 - 5 } 1. & & Frequency & Percentage \\
\cline { 3 - 5 } & Excellent & $96-100$ & 0 & $0 \%$ \\
2. & & & $0 \%$ \\
3. & Very Good & $86=95$ & 0 & $5 \%$ \\
4. & Good & $76-85$ & 0 & $35 \%$ \\
5. & Fairly Good & $66-75$ & 7 & $25 \%$ \\
6. & Fair & $56=65$ & 5 & $30 \%$ \\
7. & Poor & $46-55$ & 6 & $10 \%$ \\
\hline \multicolumn{2}{r}{ Total } & $0-45$ & 2 & $100 \%$ \\
\hline
\end{tabular}

\subsubsection{The Result of Post-Test}

The students' pre-test from the second grade of students' of SMP Negeri 1 Bambang shows that the lowers score of pre-test was 65 and the highest was
100 from the total number of students was 20 . From the score above, the researcher concluded that the vocabulary of the students has improved. It means that the students were considered different after treatment.

Table 3. Classification, Frequency, and Percentage of the Students' Post-test

\begin{tabular}{ccccc}
\hline \multirow{2}{*}{ No. } & \multirow{2}{*}{ Classification } & Score & \multicolumn{2}{c}{ Post-Test } \\
\cline { 4 - 5 } & & & Frequency & Percentage \\
\hline 1. & Excellent & $96-100$ & 1 & $10 \%$ \\
2. & Very Good & $86-95$ & 7 & $35 \%$ \\
3. & Good & $76-86$ & 8 & $40 \%$ \\
4. & Fairly Good & $66-75$ & 4 & $20 \%$ \\
5. & Fair & $56-65$ & 0 & 0 \\
6. & Poor & $45-55$ & 0 & 0 \\
7. & Very Poor & $0-45$ & 0 & 0 \\
\hline \multicolumn{2}{c}{ Total } & 20 & $100 \%$ \\
\hline
\end{tabular}

The classification of the post-test is presented in the following table. The table shows that after teaching vocabulary by Chalk Down, Turn Around Game, some students got excellent, very good, sound, and reasonably good in the post-test. Moreover, none of the students got a fair, poor, and very poor

\subsubsection{The Students Score}

As has been clarified formerly in the procedure of collecting data, the researcher conducted the test that was pre-test and post-test. The pre-test was applied before giving the treatment, while the post-test was giving after doing the treatment.
The students' total score of pre-test $\left(\sum \mathrm{x}^{1}\right)$ was 1.205 , and the student's total score of post-test $\left(\sum x^{2}\right)$ was 1.700. Gain/difference between the matched pairs $\left(\sum \mathrm{D}\right)$ was 495 and the total of square gain $\sum \mathrm{D}^{2}$ ) was 12.375. Based on the explanation above, the researcher stimulated the students to score the table below:

\subsubsection{The Comparison Between Pre-test and Post- test Scoring Classification}

The raw score of the students' vocabulary achievement was classification into seven levels. The scoring classifications of student's pre-test and post-test can be explained as follows:

Table 4. Comparison Scoring Classification of Students' Pre-test and Post-test

\begin{tabular}{ccccc}
\hline No. & Classification & Score & Pre-Test & Post-Test \\
\hline 1. & Excellent & $96-100$ & 0 & 1 \\
2. & Very Good & $86-95$ & 0 & 7 \\
3. & Good & $76-85$ & 0 & 8 \\
4. & Fairly Good & $66-75$ & 7 & 4 \\
5. & Fair & $56-65$ & 5 & 0 \\
6. & Poor & $46-55$ & 6 & 0 \\
7. & Very Poor & $0-45$ & 2 & 0 \\
\hline
\end{tabular}


The table above shows a comparison between the pre-test and post-test scores was significantly different by looking at the explanation below:

No student got excellent, very good, and a good score in the pre-test, but students only got a pretty good, fair, poor, and very poor score. While in the post-test, there were students who got excellent, outstanding, good, and relatively good. Furthermore, none of the students got a fair, poor and very poor.

The scores of students have increased after doing treatment using Chalk Down, Turn Around Game.

3.1.5 The comparison between students' rate frequency score in pre-test and post-test

Table 5. Classification Rate Percentage of the Students' Pre-test and Post-test

\begin{tabular}{|c|c|c|c|c|}
\hline No & Classification & Score & Pre-Test & Post-Test \\
\hline 1. & Excellent & $96-100$ & $0 \%$ & $5 \%$ \\
\hline 2. & Very Good & $86-95$ & $0 \%$ & $35 \%$ \\
\hline 3. & Good & $76-85$ & $0 \%$ & $40 \%$ \\
\hline 4. & Fairly Good & $66-75$ & $35 \%$ & $20 \%$ \\
\hline 5. & Fair & $56-65$ & $25 \%$ & $0 \%$ \\
\hline 6. & Poor & $46-55$ & $30 \%$ & $0 \%$ \\
\hline 7. & Very Poor & $0-45$ & $10 \%$ & $0 \%$ \\
\hline \multicolumn{3}{|c|}{ Total } & $100 \%$ & $100 \%$ \\
\hline
\end{tabular}

Based on table 4.7 above showed that the rate percentage of the student's vocabulary. In the pre-test, no students or $0 \%$ classified got excellent, very good, and good, but students only got a fairly good, fair, poor, and very poor classified. While in the post-test, there were students who got excellent, very good, good, and fairly good. Furthermore, none of the students or $0 \%$ got a fair, poor and very poor. From the explanation, the researcher concluded that there is a significant improvement in students' vocabulary achievement between pre-test and post-test.

\subsubsection{The students' mean score and gain}

After calculating the result of the students' pre-test, post-test, and gain, the researcher also calculating the mean scores of this research. It was aimed to know the differences in students' vocabulary in pre-test and post-test. The means score and gain were presented in the following table below.

Table 6. The Students' Mean Score of Pre-test, Posttest, and Gain

\begin{tabular}{ccc}
\hline Variable & $\begin{array}{c}\text { Total } \\
\text { Score }\end{array}$ & $\begin{array}{l}\text { Mean } \\
\text { Score }\end{array}$ \\
\hline Pre-Test $\left(\mathrm{x}^{1}\right)$ & 1.205 & 60.25 \\
Post Test $\left(\mathrm{x}^{2}\right)$ & 1.700 & 85 \\
Gain $(\mathrm{D})$ & 495 & 24.75 \\
\hline
\end{tabular}

The students' total score of pre-test $\left(\sum \mathrm{x}^{1}\right)$ was 1.205 with the mean score of 60.25 , which classified as fair, while the total score of post-test $\left(\sum \mathrm{x}^{2}\right)$ was 1.700 with the mean score of 85 , which classified as good. Moreover, the total score of gain was 495, with a mean score of 24.75 .

\subsubsection{Analysis data using formula}

a) Mean Score of Pre-Test

$\sum X^{1}=1.205$

$N=20$

$\mathrm{X}^{1}=\frac{\sum \mathrm{X}^{1}}{N}$

$=\frac{1.205}{20}$

$=60.25$

The mean score of students' pre-test ( $\left.x^{l}\right)$ was 60.25

b) Mean Score of Post-Test

$\sum X^{2}=1.700$

$N=20$

$$
\mathrm{X}^{2}=\frac{\sum \mathrm{X}^{2}}{N}
$$

$=\frac{1.700}{20}$

$=85$

The mean score of post-test $\left(x^{2}\right)$ was 85

c) Mean Score of Gain

$$
\begin{aligned}
& \quad \frac{\sum D}{N} \\
& D=\frac{495}{20} \\
& =24.75
\end{aligned}
$$

The mean score gain (D) was 24.75 . 
Table 7. The Mean Score of the Students' Pre-test and Post-test

\begin{tabular}{cc}
\hline Mean Score Of Pre-Test & $\begin{array}{c}\text { Mean Score Of } \\
\text { Post-Test }\end{array}$ \\
\hline 60.25 & 85 \\
\hline
\end{tabular}

As we can see in the table above, the students' pre-test score was 60.25 that can be classified into appropriate score classification, while the mean score of the students' post-test is 85 that classified as a good score classification. So the researcher concluded that the mean score of the post-test was higher than the pre-test score. It means that using Chalk Down, Turn Around Game could improve the English vocabulary of the Second Grade Students of SMP Negeri 1 Bambang.

\subsubsection{T-test value}

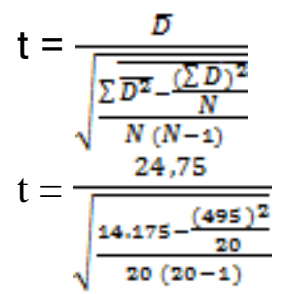

$t=\frac{24,75}{\sqrt{\frac{14.175 \frac{245,050}{20}}{20(19)}}}$

$\mathrm{t}=\frac{24,75}{\sqrt{\frac{14,175-12^{252.5}}{880}}}$

$\mathrm{t}=\frac{24_{8} 75}{\sqrt{\frac{1922.5}{880}}}$

$\mathrm{t}=\frac{24.75}{\sqrt{5.059}}$

$\mathrm{t}=\frac{24,75}{2.24}$

$$
\mathrm{t}=11.049
$$

The use of a t-test in this research was to know the students' significance in students' vocabulary after treatment by using Chalk Down, Turn Around Game. Calculating the result of the t-test value in the following.

Table 8. The Value of T-test and T-table

\begin{tabular}{ccc}
\hline Variable & T-Test Value & T-Table Value \\
\hline Pretest-Posttest & 11.049 & 2.092 \\
\hline
\end{tabular}

The table above showed that the t-table was smaller than the t-test value of the students' vocabulary acquisition, where the value of the t-test was 11.049 whiles the value of the t-table was 2,092. It could be concluded that there were significant differences between the result of the students' pre-test and post-test.

\subsubsection{Hypothesis testing}

For level significant $d f=n-1 \quad(d f=20-1)$ thus the value of t-table found used the interpolation system. The formula used and the procedure in finding out the value of df 19 was presented as follows: to find out the degree of freedom (df), the researcher used the following formula:

$$
\begin{aligned}
& d f=N-1 \\
& d f=20=1 \\
& d f=19
\end{aligned}
$$

For the level of significance $(\mathrm{D})=0,05 \%$ and degree of freedom $(\mathrm{df})=19$, and t-test value (11.049) was higher than the value of t-table $(2,092)$, it means that the null hypothesis (H0) of this research was rejected. The alternative hypothesis (H1) was accepted because there was a significant difference between students' pre-test and post-test using Chalk Down, Turn Around Game in teaching vocabulary.

Based on the analysis above, the researcher concluded a significant difference between the students' scores from pre-test and post-test by using Chalk Down, Turn Around Game. In other words, it can be concluded Chalk Down, Turn Around Game improved the students' vocabulary.

\section{Discussion}

In this section, the researcher explains the results of the use of Chalk Down, Turn Around Game in improving the vocabulary of second-grade students of SMP Negeri 1 Bambang related to the research question where the pre-test is given before being given treatment to ensure previous students' knowledge of vocabulary mastery. The pre-test was carried out on Monday, October 26th, 2020. Students participated for 60 minutes; researchers distributed test questions and asked students to answer the question based on their skills.

After giving the pre-test, students are given treatment using Chalk Down, Turn Around Game to teach vocabulary. The treatment was carried out for three meetings. Each meeting lasted 90 minutes, starting at 07:30-09:00 A.M. after the treatment was complete, the researcher took another meeting on October 20th, 2020, for a post-test, so the researcher also ended on October 20th, 2020.

At the first meeting of treatment, the researcher begins the learning process. The researcher informs about what that they will be doing until three meetings. The first meeting about adjectives, the second meeting about verbs, and the last meeting about adjectives and verbs. The researcher also informed that every learning process would be carried out using Chalk Down, Turn Around Game. Students are also expected to understand the material by using the game used in every meeting. Those who do not understand the material may ask the 
researcher and the researcher will explain until they understand the material. Then, the researcher divided them into three groups. 2 groups consisting of 7 members and 1 group consisting of 6 members. Then the students sit according to their groups in a circulation position. The researcher gave 20 words of adjectives. Each group will be translated the word and remembered it within 15 minutes. After the time finished, each group collects the translation result.

The researcher instructed to do Chalk Down, Turn Around Game with each member of the group took a turn to come forward. The researcher read out a word that had been translated, and students wrote the word quickly (seconds), then turn around and was replaced by other members of each group. After the game is over, the researcher asks students about the new vocabulary they have obtained, and instructs the students to rewrite the words written on the blackboard/whiteboard with the appropriate translation.

In the second meeting of treatment, the researcher gave material about verbs, explained the meaning and examples of verbs. After that, the researcher instructed students to sit with their groups and to did activities like the previous meeting.

In the third meeting of treatments, the researcher re-explained the difference between adjectives and verbs to understand better. After that, the researcher instructed students to sit with their groups and to did activities such as previous meetings using Chalk Down, Turn Around Game, and ask students to explain the difference between adjectives and verbs again.

The post-test was held on Saturday, November 20th, 2020. The researcher gave a post-test after the treatment and gave a new question to the students to do it. The researcher gave 60 minutes to answer the questions according to what they know.

Based on the result above, the researcher concluded that the use of Chalk Down, Turn Around Game can improve students' vocabulary at the second-grade students of SMP Negeri 1 Bambang, Mamasa Sulbar. It can improve the students' vocabulary in three treatments. This result is in line with Setyaningsih (2015) that showed the students' activity during the treatment, they appreciated the game strategy can improve the students' vocabulary mastery and it also indicated that it helps the students in learning vocabulary.

In each treatment carried out for three meetings, the researcher uses Chalk Down, Turn Around Game to teach vocabulary, and students have increased knowledge after carrying out the learning process using Chalk Down, Turn Around Game. The highest score of the pre-test score the students got in the pretest was 75 (before being given treatment) with the reasonably good categorized while the highest score the students got in post-test was 100 as categorized excellent (After doing the treatment given). It means that the use of Chalk Down, Turn Around Game can improve students' vocabulary in teaching and learning vocabulary of students from a good score for the excellent score obtained.

The mean score of the students' post-test was higher (85) than the students' pre-test $(60,25)$. It means that the null hypothesis (H0) of this research was rejected, and the alternative hypothesis (H1) was accepted because there was a significant difference between students' pre-test and post-test by Using Chalk Down, Turn Around Game in teaching vocabulary.

Students' classification of values in the pre-test is explained by looking at the score and percentage. Where there are seven students or $35 \%$ of students, get the fairly good classification (5 students get a score of 70 and 2 students to get a score of 75) 5 students or $25 \%$ of students get proper classifications (2 students get a score 60 and 3 students get a score 65) 6 students or $30 \%$ students get the poor classification (4 students get a score 50 and 2 students get a score 55). Two students, or $10 \%$ of students, get the very poor classification (1 student gets a score of 35 , and 1 student gets a score of 45).

The post-test also uses the same classification. The highest classification is excellent, which has been achieved by one student with a percentage of $5 \%$ of the total sample. Seven students have achieved the excellent classification with a percentage of $35 \%$, eight students have achieved the excellent classification with a percentage of $40 \%$, and then four students have achieved the fairly good classification with a percentage of $20 \%$ of the total sample. Furthermore, there was no percentage of students in that classification to fair, poor, and very poor classifications. T-table was smaller than the $\mathrm{t}$ test value of the students' vocabulary. Where the value of the t-test (11.049), while the value of the table was (2.092) for the degree freedom, was $(0,05)$ and df (19). It could be concluded that there were significant differences between the result of the students' pre-test and post-test

In three meetings with students, some changes occurred in the classroom. At the first meeting, students tended to be silent and did not respond when the researcher explained the material. Students were also only silent when the researcher asked questions or was allowed to ask questions. However, when playing the game, the students were very excited and united. Students are also more active in speaking and learning the words they will write on the board. At the next meeting, the students were very enthusiastic about learning by using Chalk Down, Turn Around Game. Students were active in writing and asked questions about the meaning of 
words they did not know. At the last meeting, students were still excited about learning to use the game. So that during the post-test, they feel more relaxed in doing the questions by knowing the words they have learned. This is in line with Febriansyah (2016) study which mentioned that the students' involvement and classroom interaction during the implementation of the game were improved and it was showed by students' enthusiasm during the game. It also connects the idea from Sari (2017) that revealed that the implementation of Spelling Bee game can improve students' vocabulary mastery. The questionnaire result also showed the strategy helps students recall and memorize the vocabulary quickly and carefully.

Based on the discussion above, using Chalk Down, Turn around Game was good enough to improve students' vocabulary, especially in Adjectives and Irregular Verbs. It could be proved by seeing the improvement of students' pre-test and post-test scores. Thus, it indicates that the second-grade students of SMP Negeri 1 Bambang improved their vocabulary ability, especially using Chalk Down, Turn Around Game.

\section{Conclusion}

Vocabulary is an essential language learning ability, including English, because, without vocabulary, nothing can be conveyed. Nevertheless, one of which is the lack of student interest in learning vocabulary due to the lack of learning media that can support the teaching and learning process. So, the researcher used Chalk Down, Turn Around Game to teach vocabulary at the second grade of SMP Negeri 1 Bambang to improve students' vocabulary.

Based on the previous chapter's findings, the researcher concluded that teaching vocabulary, especially in synonym and antonyms, using Chalk Down and Turn Around Game can improve the students' vocabulary in the second-grade students from SMP Negeri 1 Bambang.

It can be seen from the total score of pre-test was 1.205 while the total score of post-test was 1.700 . The mean score of the pre-test was 60,25, and the mean score of the post-test was 85 . It means that the total score and mean score of post-test was higher than the total score and mean score of pre-test, and at level ttest value was 11.049 while t-table was 2,092.

\section{References}

Anisa, I. (2011). Improving Students' Vocabulary Mastery Using Experiential Learning (A Classroom Action Research on the Sixth Grade of SDN Banaran 01 in the Academic Year of 2009/2010) (Doctoral dissertation, UNS (Sebelas Maret University)).

Cahyani, H. A. N. (2016). Improving Students' Vocabulary Mastery by Using Charades (A
Classroom Action Research at Second Grade of MTs Assyafi'iyah Gondang Tulungagung in the Academic Year of 2015/2016). THESIS.IAIN Tulung Agung.

Febriyansyah, I. (2016). Improving students' vocabulary mastery through Bingo game for grade $\mathrm{X}$ of SMAN 4 Purworejo in the academic year of 2014/2015. English Language Teaching Journal, 5(3).

Gallant, D. (2016). Chalk Down, Turn Around. .Retrieved from http://www.wordbuff.com/html.

Hakim, L. N., \& Syafei, A. F. R. (2018). Using Vocabulary Dice Game in Teaching Vocabulary to Elementary School Students. Journal of English Language Teaching, 7(4).

JANNAH, N. F. (2010). Improving The Students' Vocabulary Mastery through Montessori Method (A Classroom Action Research at SD Muhammadiyah Kottabarat, Surakarta) (Doctoral dissertation, Universitas Muhammadiyah Surakarta).

Israilovich, I. U. (2019). Practical Strategies to Teach Vocabulary Through Games in EFL Beginner Classes: the Case Study of Some Secondary Schools in Namangan Region. International Journal on Integrated Education, 2(6), 94-96.

Lessard-Clouston, M. (2013). Word Lists for vocabulary learning and teaching. CATESOL Journal, 24(1), 287-304.

Lestiyaningsih, R. (2017). The effectiveness of using video for teaching procedure text writing. A study of Eight Semester Students of English Study Program at IAIN Surakarta) IAIN Surakarta (Unpublished Thesis). IAIN Surakarta) IAIN Surakarta

Maritha, E., \& Dakhi, S. (2017). The Effectiveness of Picture: An Empirical Evidence in Vocabulary Mastery. Online Submission, 3(3), 163-176.

Mills, G. E., \& Gay, L. R. (2019). Educational research: Competencies for analysis and applications. Pearson. One Lake Street, Upper Saddle River, New Jersey 07458.

Rohmatillah, R. (2014). A Study On Students' Difficulties in Learning Vocabulary. English Education: Jurnal Tadris Bahasa Inggris, 6(1), 75-93.

Kabooha, R., \& Elyas, T. (2018). The Effects of YouTube in Multimedia Instruction for Vocabulary Learning: Perceptions of EFL Students and Teachers. English Language Teaching, 11(2), 72-81. 
Sari, I. P., Asahra, E. E., \& Yana, Y. (2019). Improving Students' Vocabulary Mastery Using English Song. Project (Professional Journal of English Education), 2(3), 410-415.

Sari, Y. (2017). The Effect of Spelling Bee Game on Students' Vocabulary Mastery (Doctoral dissertation, UIN Ar-Raniry Banda Aceh).

Setyaningsih, F. E. (2015). The Use of Word Clap Game to Improve Students' Vocabulary Mastery (A Classroom Action Research at the Eighth Grade Students of SMP N 3 Ungaran in the Academic year of 2014/2015) (Doctoral dissertation, Universitas Negeri Semarang).

Wantini, D. (2010). Improving Students' Vocabulary Mastery Using Realia. Unpublished Thesis. Surakarta: Universitas Sebelas Maret.

Yuliana, S. (2011). Improving student's vocabulary by using Riddles game at the second grade students of MTs Miftahul Ulum Bendung Mojokerto (Doctoral dissertation, IAIN Sunan Ampel Surabaya).

Yuliani, S. (2017). Teaching English vocabulary by using guessing game to the fifth grade students 117 Palembang. English Community Journal, 1(2),123-129 